\title{
Systemic Acquired Resistance Induced by Compatible and Incompatible Tomato Mosaic Viruses Effectively Controls Bacterial Spot and Speck Diseases in Tomato
}

\author{
Elena Shopova, Bistra Mihailova, Dessislava Todorova *, Iskren Sergiev ${ }^{(D)}$ and \\ Elisaveta Stoimenova \\ Institute of Plant Physiology and Genetics, Bulgarian Academy of Sciences, Acad. G. Bonchev Str., Bl. 21, \\ 1113 Sofia, Bulgaria; kostei@abv.bg (E.S.); bistrasm@abv.bg (B.M.); iskren@bio21.bas.bg (I.S.); \\ el.stoimenova@abv.bg (E.S.) \\ * Correspondence: dessita@bio21.bas.bg
}

Received: 24 June 2020; Accepted: 15 July 2020; Published: 17 July 2020

\begin{abstract}
Tomato plants (Solanum lycopersicum L.) cv. Moperou, which possess gene Tm-2 for resistance against tomato mosaic virus (ToMV), were pre-inoculated with compatible pathotype P2 or incompatible pathotype P0 strains of ToMV and subsequently challenge infected with Pseudomonas syringae pv. tomato and Xanthomonas vesicatoria. It was found that both types of virus strains, compatible and incompatible, induced systemic acquired resistance (SAR), which protected plants from subsequent pathogen infection. The percentage of protection of the compatible ToMV pathotype P2 strain was $100 \%$ against both bacterial infections, while that of the incompatible ToMV pathotype P0 strain varied from 26 to $77 \%$ within the timeline and depended on the pathogen races. The SAR induced by ToMV was confirmed by the increased antioxidant defense and hydrogen peroxide content in the leaves of tomato plants inoculated with compatible and incompatible ToMV strains.
\end{abstract}

Keywords: antioxidant defense; Pseudomonas syringae pv. tomato; SAR; ToMV; Xanthomonas vesicatoria

\section{Introduction}

The cultivated tomato, Solanum lycopersicum L., belongs to the family Solanaceae, along with several other commercially important crops, such as potato, eggplant, and bell and chili peppers; all of them are used as food. Tomato is one of the world's most frequently consumed crop vegetables because it is an essential ingredient in a great assortment of raw, cooked, or processed foods. It is grown worldwide for local use or as an important export crop [1,2].

During their growth and development, crops interact with diverse biotic agents (pathogens), such as fungi, bacteria, viruses, nematodes, protozoa, etc.- -the so-called biotic stress [3]. One of the first responses of plants to pathogen infection is the production of reactive oxygen species (ROS), which are directly toxic to the pathogens [4] and also act as an important regulatory mechanism [5]. An oxidative burst is followed by an accumulation of antioxidants [6]. A primary infection caused by different pathogens may induce a plant immune response to a pathogen attack named systemic acquired resistance (SAR), which is characterized by plant resistance to a subsequent pathogenic infection [6,7]. It is known that SAR activation is associated with the stimulation of the activity of several antioxidant enzymes, such as peroxidases, catalase, and superoxide dismutase, enzymes of the ascorbate-glutathione cycle, as well as the level of non-enzymatic antioxidants, mainly ascorbate, glutathione, $\alpha$-tocopherol, proline, plant phenolics, etc. [3,6]. Usually, the SAR pathway is activated after the formation of necrotic lesions due to primary pathogen invasion, either as a part of the hypersensitive response (HR) or as a symptom of disease and results in the development of a broad-spectrum, systemic resistance to subsequent attack $[6,8,9]$. 
Tomato mosaic virus (ToMV) belongs to the genus Tobamovirus in the family Virgaviridae. It is one of the earliest described viruses in plants along with tobacco mosaic virus (TMV). ToMV provokes a serious and extremely contagious disease, not only in tomato but in other crops as well. ToMV disease is not easy to identify because the symptoms vary widely depending on the variety, age, and plant development stage of the infected plant, the virus strain, and the environmental conditions $[2,10]$. However, during the past decades, it was reported that tomato seedlings systemically infected with the symptomless strain of ToMV are protected against subsequent bacterial inoculation with Pseudomonas syringae pv. tomato (Pst) and Xanthomonas vesicatoria (Xv) [11-13]. It could be suggested that the ToMV activates a plant's unspecific defense mechanisms, which control the spread of bacterial infection, i.e., SAR has developed in the primed tomato plants. This suggestion is dissimilar to the hypothesis that only necrotic pathogens could be SAR elicitors [14-16]. The question remains whether the incompatible viral strains that do not cause HR can induce SAR.

The aim of this study is to compare SAR effectiveness, induced by compatible and incompatible ToMV strains, on disease development of different strains of Pseudomonas syringae pv. tomato (Pst) and Xanthomonas vesicatoria $(\mathrm{Xv})$ in tomato plants. Our results demonstrated, for the first time, that the incompatible ToMV strain also induced effective SAR against subsequent infection, although it was less than that observed in plants inoculated with the compatible ToMV strain.

\section{Materials and Methods}

The tomato (Solanum lycopersicum L.) plant cv. Moperou (bearing the Tm-2 resistance gene against ToMV) susceptible to Pseudomonas syringae pv. tomato (Pst) and Xanthomonas vesicatoria (Xv) was used. The ToMV strains J (compatible pathotype P2) and GM-0 (incompatible pathotype P0) were used for primary inoculation in concentration $10 \mu \mathrm{g} / \mathrm{mL}$. Bacterial strains PstR0 (№ 31pt), PstR1 (№ 27pt), XvT1 (№ 24t), XvT2 (№ 53t), and XvT3 (№ 30t) were applied as challenge inoculation. The suspensions were prepared from a $36 \mathrm{~h}$ culture of Pst in a concentration of $10^{4} \mathrm{cfu} / \mathrm{mL}$ and of $\mathrm{Xv}$ at $10^{8} \mathrm{cfu} / \mathrm{mL}$ concentration, and plants were inoculated by vacuum infiltration. The tomato seedlings $\mathrm{cv}$. Moperou in developmental phase 1-2 true leaves were divided into three groups for the first inoculation or treatment: (1) C-(control) mock-treated; (2) P0-inoculated with ToMV GM-0 strain; (3) P2-inoculated with ToMV J strain. The seedlings from each of the three variants were subdivided into four groups: groups 1, 2, and 3-inoculated with Pst (R0 and R1) and $\mathrm{Xv}_{\mathrm{v}}$ (T1, T2, and T3) bacterial strains on 7, 14, and 21 days past inoculation (dpi) - and group 4-the seedlings were used for biochemical analyses on 7, 14, and $21 \mathrm{dpi}$. Twenty seedlings per each treatment were used for assessment of bacterial disease severity development.

The hypersensitive reaction (HR) was recorded $24 \mathrm{~h}$ after inoculation with bacterial strains, and the spots on the foliage were recorded $4-5$ days later. The number of spots per plant and grade of bacterial disease were scored by the scale of Chambers and Merriman [17] for Pst and by the scale of Sotirova and Beleva [18] for $\mathrm{Xv}$. The classification of plants was made on the basis of the mean score of infestation (ms): immune (0), 0; resistant (1), 0.01-0.6; moderately sensitive (2), 0.61-1.49; sensitive (3), 1.50-2.99; highly sensitive (4), over 3.

The percentage of protection was calculated as $100-(100 \times X / Y)$, where $X$ is the disease severity of bacterial diseases in ToMV-inoculated plants, and $\mathrm{Y}$ is the bacterial disease severity in mock-treated plants [14].

Selected biochemical parameters such as the content of non-enzymatic antioxidantsthiol-containing compounds, total phenols, and free proline; the content of stress biomarkershydrogen peroxide $\left(\mathrm{H}_{2} \mathrm{O}_{2}\right)$ and malondialdehyde (MDA); and activities of antioxidant enzymessuperoxide dismutase, guaiacol peroxidase, and catalase were measured. Each sample consisted of a minimum of three simple leaves from a fourth complex leaf, harvested from a minimum of three randomly chosen plants.

Fresh leaf material (approximately $300 \mathrm{mg}$ ) was ground with $0.1 \%(w / v)$ trichloroacetic acid and centrifuged for determination of the content of stress biomarkers and non-enzymatic antioxidants. 
Free proline was determined after supernatant derivatization with acid ninhydrin, and absorbance was recorded at $520 \mathrm{~nm}$ [19]. Total phenolic content was determined by the supplementation of supernatant with the Folin-Ciocalteu reagent and sodium carbonate. The absorbance of the reaction mixture was read at $725 \mathrm{~nm}$ [20], and the content was calculated using a standard curve prepared with known concentrations of gallic acid as the reference standard. The content of free thiol-containing compounds was determined after the addition of Ellman's reagent, then absorbance was recorded at $412 \mathrm{~nm}$, and the quantity was calculated by using the molar extinction coefficient of $13.6 \mathrm{mM}^{-1} \mathrm{~cm}^{-1}$ [21]. Hydrogen peroxide concentration was estimated spectrophotometrically according to Reference [22] and was calculated using a standard curve. Malondialdehyde content was estimated as a parameter reflecting biomembrane integrity deterioration and was determined as the thiobarbituric acid reagent product according to Reference [23] by using the molar extinction coefficient of $155 \mathrm{mM}^{-1} \mathrm{~cm}^{-1}$.

For the assay of antioxidant enzymes, approximately $250 \mathrm{mg}$ of fresh plant material was ground in $100 \mathrm{mM}$ of potassium phosphate buffer (pH 7.0) containing $1 \mathrm{mM}$ EDTA and $1 \%$ polyvinylpyrrolidone $(\mathrm{w} / \mathrm{v})$. The homogenates were centrifuged for $30 \mathrm{~min}\left(15,000 \times \mathrm{g}, 4^{\circ} \mathrm{C}\right)$. The enzyme activities were determined according to the following methods: superoxide dismutase (SOD, EC 1.15.1.1) [24], guaiacol peroxidase (POX, EC 1.11.1.7) [25], and catalase (CAT, EC 1.11.1.6) [26].

Total SOD activity was estimated by monitoring the inhibition of the photochemical reduction of nitrobluetrazolium (NBT). One unit of SOD activity was defined as the amount of enzyme required to cause a $50 \%$ inhibition of the reduction of NBT, which was monitored at $560 \mathrm{~nm}$.

POX activity was measured using guaiacol as an electron donor and following the absorbance increase at $470 \mathrm{~nm}\left(\varepsilon=26.6 \mathrm{mM}^{-1} \mathrm{~cm}^{-1}\right)$ for $60 \mathrm{~s}$.

CAT activity was monitored following the decomposition of hydrogen peroxide and was determined by measuring the decrease of absorbance for $60 \mathrm{~s}$ at $240 \mathrm{~nm}\left(\varepsilon=36.8 \mathrm{mM}^{-1} \mathrm{~cm}^{-1}\right)$.

The data were statistically analyzed by ANOVA and Duncan's multiple range test at $p<0.05$ and $p<0.001$.

\section{Results and Discussion}

3.1. Assessment of Disease Severity and SAR Effectiveness in Tomato Plants Pre-Inoculated with Compatible and Incompatible ToMV Strains and Challenge Inoculated with Bacterial Strains

In this study, we present data on the induction of SAR by pre-inoculation of tomato plants cv. Moperou with ToMV incompatible (GM-0) and compatible (J) strains against subsequent bacterial diseases caused by Pseudomonas syringae pv. tomato (Pst) and Xanthomonas vesicatoria $(\mathrm{Xv})$.

This tomato cultivar bears gene Tm-2 for resistance against ToMV, but after the introduction of resistant tomatoes in the field, resistance-breaking virus isolates were documented [27-29]. ToMV J strain is compatible, and it systemically infects tomato plants cv. Moperou, and yellow mosaic develops on the young leaves. This reaction is considered as HR. ToMV GM-0 strain is incompatible and is not able to cause visible HR symptoms.

In plants infected only with Pst (R0, R1) and $\mathrm{Xv}_{\mathrm{v}}(\mathrm{T} 1, \mathrm{~T} 2, \mathrm{~T} 3)$ bacterial strains, typical symptoms of disease were observed. No healthy plants ( 0 and HR) and plants with a low degree (1) of infection (Figure 1) were detected seven days after mock-inoculation. These results indicate that the tomato variety used in the experiment was susceptible to these bacteria. Additionally, the youngest plants were the most sensitive. The sensitivity decreased with plant age, and, at 14 and $21 \mathrm{dpi}$, some plants with a low degree (1) of infection appeared. 


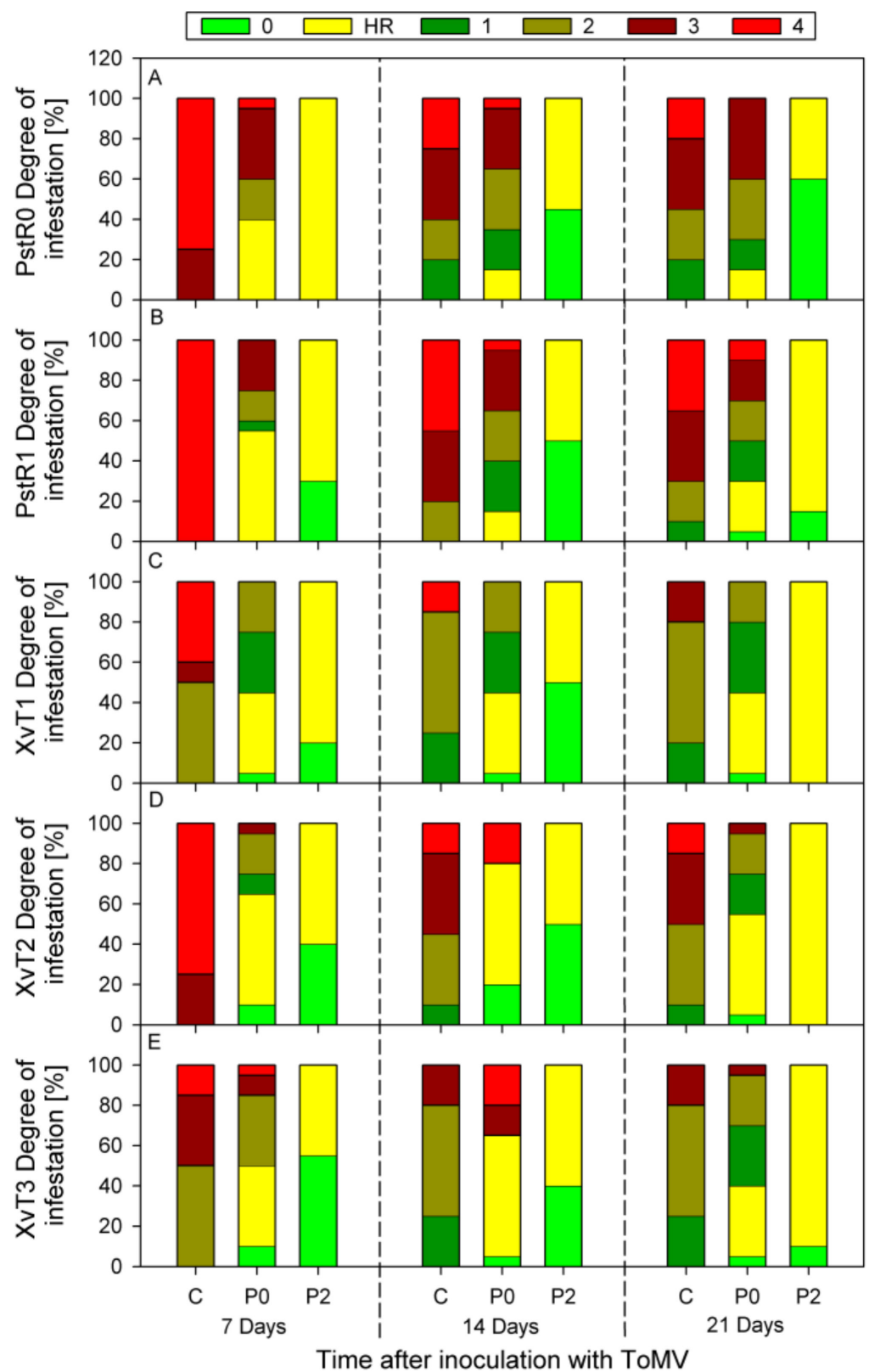

Figure 1. Degree of infestation from Pst (R0, R1) and $\mathrm{Xv}_{v}(\mathrm{~T} 1, \mathrm{~T} 2, \mathrm{~T} 3)$ on tomato plants cv. Moperou, pre-inoculated with tomato mosaic virus (ToMV) incompatible strain (GM-0) P0 and with compatible (J) strain P2 $(7,14$, and $21 \mathrm{dpi})$. The classification of plants was made on the basis of the mean score of infestation: immune (0); resistant (1); moderately sensitive (2); sensitive (3); and highly sensitive (4). $\mathrm{C}=$ Control; $\mathrm{HR}=$ Hypersensitive reaction.

In plants inoculated with ToMV and subsequently infected with bacterial strains, healthy plants ( 0 and HR) were observed; in most cases, the number of plants with HR predominated (Figure 1). The plants initially infected systemically with a ToMV J strain and challenge inoculated with Pst and $X_{v}$ were healthy or developed HR, and there were no plants with symptoms of Pst and $X_{v}$ diseases. In plants inoculated with ToMV GM-0 strain, symptoms of Pst and $\mathrm{X}_{\mathrm{v}}$ did not develop in 15\% (PstR0-14 and $21 \mathrm{dpi}$ ) to 80\% (XvT2-14 dpi) of the plants. The number of infected plants with any degree of infection in groups 1, 2, 3, and 4 varied depending on the bacterial strain and the duration of time between the two infections. 
The highest degree of disease in tomato plants infected only with Pst and $X_{v}$ was observed in PstR1 (4.00), which is the maximum of this scale (Figure 2). In the mock-inoculated plants and those subsequently challenged with PstR0 and XvT2, a mean infestation score of 3.75 was detected. These values diminished with the increase in plant age but remained high in comparison to XvT1 and XvT3 bacterial races.

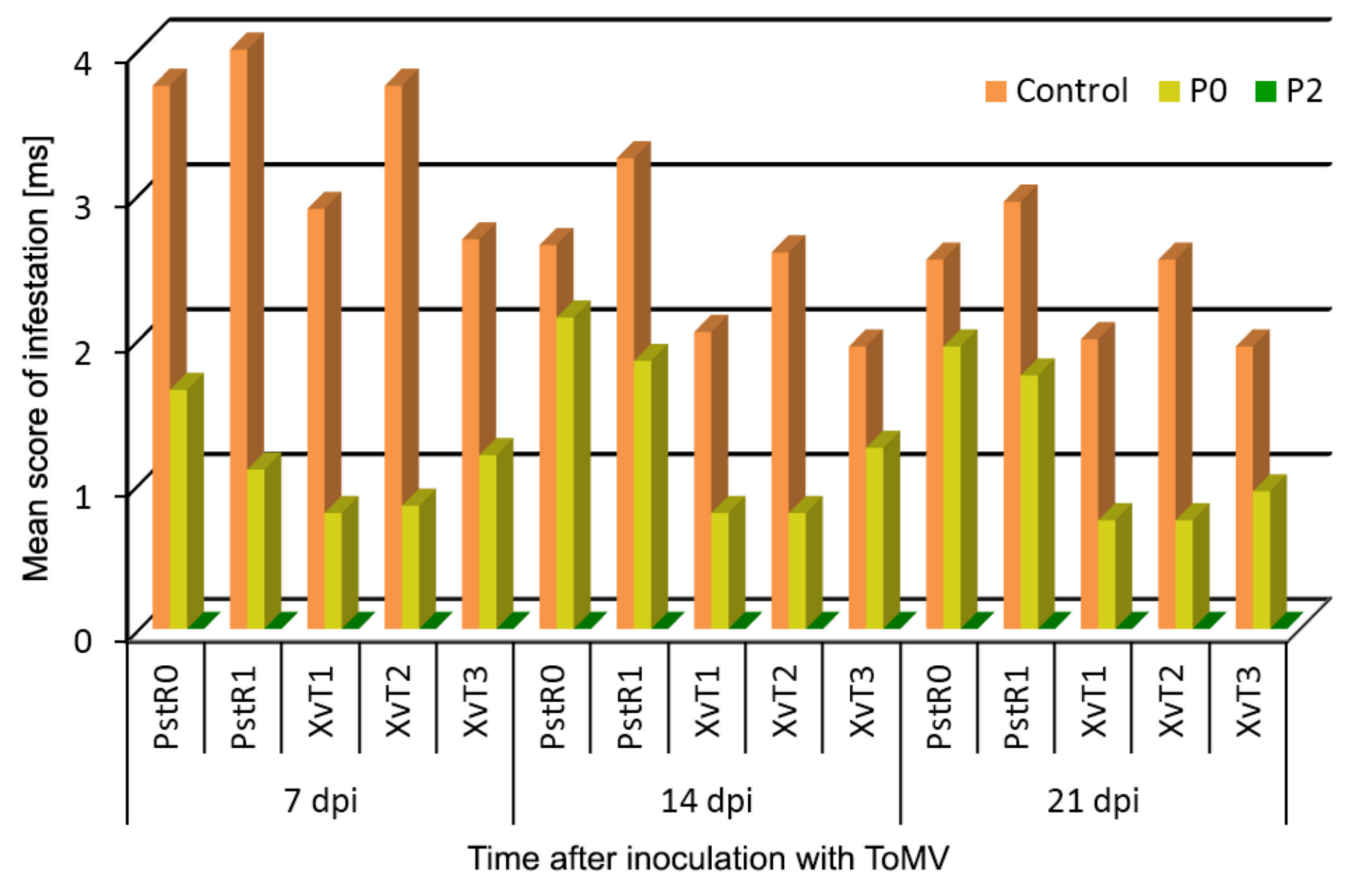

Figure 2. Mean score of infestation from Pst (R0, R1) and $\mathrm{Xv}_{\mathrm{v}}(\mathrm{T} 1, \mathrm{~T} 2, \mathrm{~T} 3)$ of tomato plants cv. Moperou pre-inoculated with ToMV incompatible strain (GM-0) P0 and with compatible (J) strain P2 (7, 14, and $21 \mathrm{dpi}$ ).

In plants inoculated with ToMV, the degree of disease of the two bacteria was significantly lower as compared to those plants inoculated with Pst and $\mathrm{Xv}_{\mathrm{v}}$ only. It could be suggested that both strains of ToMV induce SAR, which, however, differed significantly in their effectiveness. SAR induced by the compatible strain P2 of ToMV was maximal, and the mean score of infestation in these plants was 0 . So, there was no development of all bacterial strains. In plants pre-inoculated with the incompatible GM-0 ToMV strain, the degree of disease varied significantly from 0.75 to 1.95 , depending on the bacterium and its strain. The lowest degree of disease (0.75 and 0.85) was identified in XvT1 and XvT2. The mean score of the infestation value was slightly higher (0.95-1.25) in plants challenge inoculated with XvT3. In both races of Pst, the mean score of infestation values was highest (1.65 to 1.95), with the exception of PstR1 7 dpi, where it was 1.1.

The effectiveness of SAR induced by compatible and incompatible ToMV strains on the development of bacteria of the Pst $(\mathrm{R} 0, \mathrm{R} 1)$ and $\mathrm{Xv}_{\mathrm{v}}(\mathrm{T} 1, \mathrm{~T} 2, \mathrm{~T} 3)$ strains is seen from the data of protection percentages (Figure 3). The protection against bacterial infection was $100 \%$ in all variants pre-inoculated with the compatible J strain of ToMV during the whole experimental period. This is an expected result, as the virus is constantly present throughout the plant. 


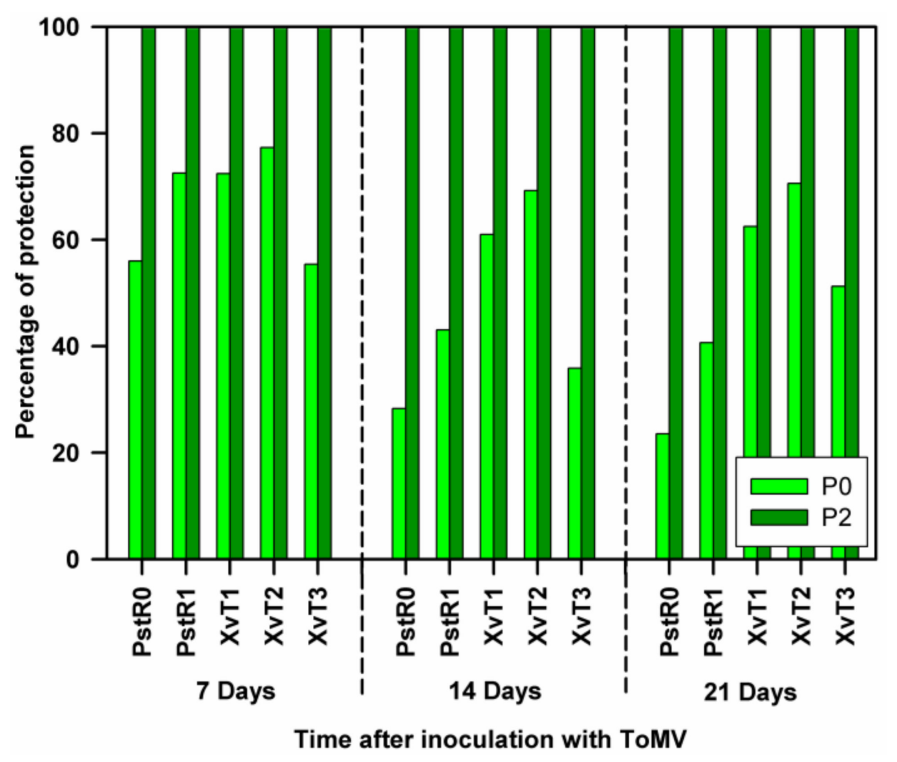

Figure 3. Effect of protection against Pst (R0, R1) and $\mathrm{Xv}_{\mathrm{v}}(\mathrm{T} 1, \mathrm{~T} 2, \mathrm{~T} 3)$ on tomato plants cv. Moperou after pre-inoculation with the ToMV incompatible strain (GM-0) P0 and with the compatible (J) strain P2 (7, 14 and 21 dpi).

In the incompatible strain, the virus was present in relatively few cells on the first leaf, and the development of the plant led to an increase in the distance between the cells with and without the virus. Therefore, a reduction in the potency of the signals leading to the onset of SAR may be expected. Comparing the percentage of protection of ToMV P0 strain against the different bacterial races, it was statistically significant $(p \leq 0.05)$ only between the seventh day and the other two time points and depended on the bacterial race. These differences were more considerable in the two races of Pst and lesser in the races of $X_{\mathrm{v}}$. The rate of protection depends on the type and race of the bacteria. We found that at $7 \mathrm{dpi}$, the rate of protection was highest in $\mathrm{XvT}_{\mathrm{vT}}(77.3 \%)$, decreased in PstR1 (72.5\%) and $\mathrm{XvT}_{\mathrm{vT}}$ (72.4\%), and was lowest in PstR0 (56\%) and XvT3 (55.4\%). At $14 \mathrm{dpi}$, compared to $7 \mathrm{dpi}$, this percentage decreased significantly in plants challenged with PstR0 (by 29.4\%) and PstR1 (by 27.7\%). In plants infected with Xantomonas, the drop in the percentage of protection was as follows: XvT3 by $19.5 \%$, $\mathrm{XvT}_{\mathrm{vT}}$ by $11.4 \%$, and $\mathrm{XvT}_{\mathrm{v}}$ by $8.1 \%$. The percentage of protection between treatments on days 14 and 21 did not differ except for XvT3.

Systemic virus-infected tomato plants are protected against subsequent bacterial diseases. This is also valid for tomato plants infected with incompatible virus strains. Both types of virus strainscompatible and incompatible-elicit SAR, which protects plants from challenge pathogen infection.

\subsection{Biochemical Analyses of Tomato Plants Inoculated with Compatible and Incompatible ToMV Strains}

The data from biochemical analyzes (Figures 4 and 5) confirmed the results of SAR investigations. We found that seven days after virus inoculation, most of the biochemical parameters were near or below the respective controls, but they tended to get higher over time. The induction of SAR by both ToMV strains was associated with a significant increase (up to three-fold at $21 \mathrm{dpi}$, as compared to mock-inoculated plants) in the amount of total phenols (Figure 4A), free proline (Figure 4B), free thiol-containing compounds (Figure 4C), and enhanced peroxidase activity (Figure 5D). Hydrogen peroxide (Figure 5C) content was also increased at 21 dpi by over $550 \%$ in ToMV inoculated plants, as compared to the mock-inoculated plants. There was no drastic change in malondialdehyde (Figure 4D) and superoxide dismutase activity (Figure 5A). Catalase activity underwent dynamic changes. At the end of the experimental period, it was elevated three-fold only in GM-0_inoculated plants (Figure 5B). 


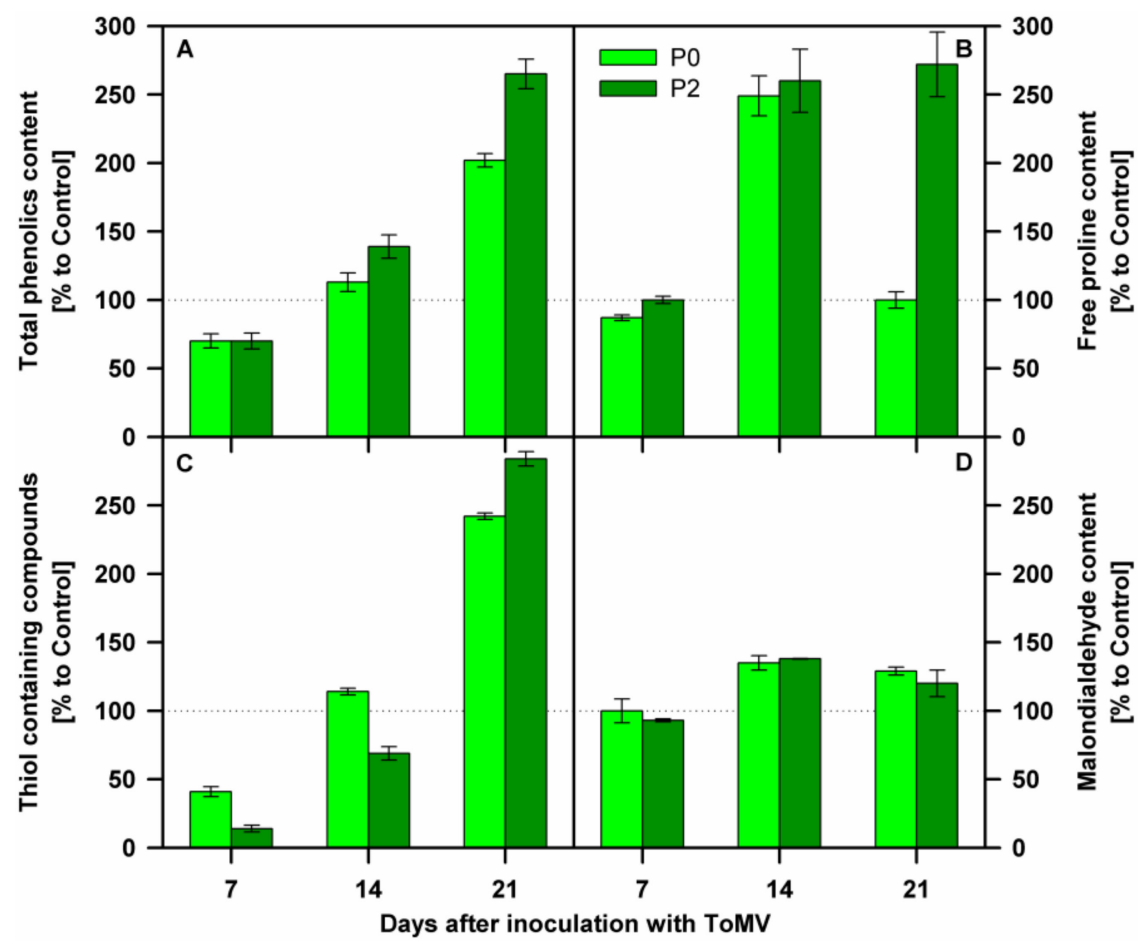

Figure 4. Mean $( \pm \mathrm{SE})$ percentage of the changes in the contents of total phenolics (A); Free proline (B); Thiol-containing compounds (C); Malondialdehyde (D) in tomato plants cv. Moperou inoculated with ToMV incompatible strain (GM-0) P0, and compatible (J) strain P2 (7, 14, and 21 dpi).

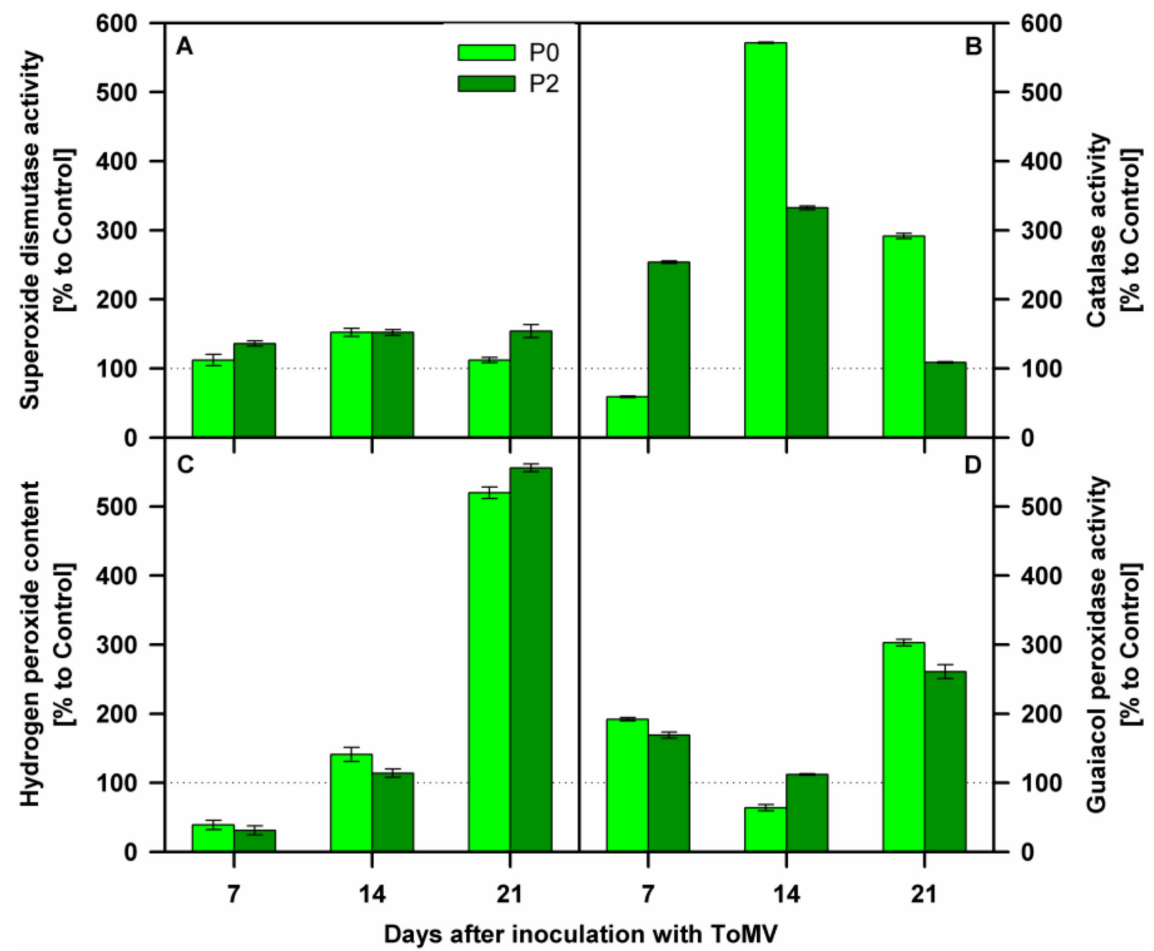

Figure 5. Mean $( \pm \mathrm{SE})$ percentage of the activity of superoxide dismutase (A); Activity of catalase (B); Content of hydrogen peroxide (C); Activity of guaiacol peroxidase (D) in tomato plants cv. Moperou inoculated with ToMV incompatible strain (GM-0) P0, and compatible (J) strain P2 (7, 14, and 21 dpi).

The antioxidant plant defense is a dynamic system, and its responses can vary in a wide range. Both up- and down-regulation has been detected under biotic and abiotic stress as well $[6,30]$. Hydrogen peroxide is one of the active forms of oxygen, which is normally formed in plant cells in 
a number of enzymatic and non-enzymatic reactions. $\mathrm{H}_{2} \mathrm{O}_{2}$ can act as a signaling molecule in low concentrations, but it becomes toxic at high levels $[3,6]$. Invasion of pathogens leads to overgeneration of hydrogen peroxide. This toxic effect is used by plants as a "weapon" in their protective responses to phytopathogens [16]. Hyperproduced $\mathrm{H}_{2} \mathrm{O}_{2}$ attacks pathogens and blocks their reproduction and/or has a direct cytotoxic effect. In addition, the infected areas combine hydrogen peroxide overproduction with inhibition of antioxidant enzyme defense systems, primarily catalase, which is the major enzyme that neutralizes excess hydrogen peroxide [6,31]. Thus, the affected areas of plant tissues die. In consequence, the spread of pathogens is blocked, which was also observed in our experiments. The results obtained for hydrogen peroxide content and catalase activity prove that inoculation with ToMV virus initiates HR, which protects plants from subsequent infection from other pathogens.

The relationship between the mechanisms that induce SAR in plants and the content of total phenols has been proven [32]. Total phenols are secondary metabolites that perform a variety of physiological functions. They are considered to be one of the most powerful antioxidant compounds in plants involved in protective reactions against phytopathogens [33]. Some phenols have antibacterial and/or antifungal properties and are synthesized specifically in response to invasion by pathogens [34-36]. The increased content of total phenols in the two groups of plants inoculated with the different strains of ToMV confirms the hypothesis that phenols play an important role in SAR induction that protects plants from pathogens.

Other antioxidants directly related to the response of plants to pathogens are thiol-containing compounds (i.e., glutathione as the major low-molecular-weight thiol) [37-40] and free proline [31,41,42]. Higher total thiols (GSH) and proline are important for proper plant defense against pathogens, via activation of HR to biotic infections and scavenging ROS, which leads to a suppression of a disease's symptom development. So, it seems that the increase detected in their content, which we also found in our experiments, is a prerequisite for the induction of SAR.

Previous investigations have pointed out that plant peroxidases are involved in defense against biotic stressors, and increased enzyme activity is associated with induction of resistance to bacterial and viral pathogens $[31,33,42,43]$. In addition, it is well known that plants respond to pathogen invasions with intensified lignification of cell walls and synthesis of specific phenolic compounds. In this process, the peroxidases are directly involved $[3,33,44]$. It can be argued that peroxidase activation is related to the induction of SAR, which has been demonstrated in our experiments.

It can be summarized that at the end of the experimental period, there is a clear relationship between the degree of protection against pathogens and the change in biochemical parameters. The increase in the content of non-enzymatic antioxidants, hydrogen peroxide, and peroxidase activity is directly correlated to the induction of SAR in plants inoculated with the compatible strain of the virus. At the same time, although to a lesser extent, this is also true for plants inoculated with the incompatible strain of the virus, which confirms the hypothesis of our study.

\section{Conclusions}

It is widely accepted that SAR can be induced only by pathogens to which plants respond with necrotic staining, including HR [8] or by pests that mechanically damage plants [45]. The systemic tomato-infesting pathogenic strain of ToMV J induces highly effective SAR against subsequent bacterial diseases. Our results demonstrate, for the first time, that an incompatible strain of ToMV GM- 0 , which is localized in the inoculated leaf only and does not induce visible necrosis in tomatoes, can also elicit effective SAR.

Author Contributions: Conceptualization, E.S. (Elisaveta Stoimenova); coordinated the research, D.T.; grew the plants, made the inoculations, assessed and interpreted the disease severity data, B.M. and E.S. (Elisaveta Stoimenova); performed the laboratory analyses, collected and interpreted the biochemical data, I.S., D.T. and E.S. (Elena Shopova); prepared manuscript and figures, I.S. and D.T.; reviewed and edited the manuscript, I.S., D.T., E.S. (Elena Shopova) and B.M. All authors have read and agreed to the published version of the manuscript.

Funding: This research received no external funding. 
Acknowledgments: In this section you can acknowledge any support given which is not covered by the author contribution or funding sections. This may include administrative and technical support, or donations in kind (e.g., materials used for experiments).

Conflicts of Interest: The authors declare no conflict of interest.

\section{References}

1. OECD. Chapter 2. Tomato (Solanum lycopersicum). In Safety Assessment of Transgenic Organisms in the Environment; OECD Consensus Documents, Harmonisation of Regulatory Oversight in Biotechnology; OECD Publishing: Paris, France, 2017; Volume 7, pp. 69-104. [CrossRef]

2. Ullah, N.; Ali, A.; Ahmad, M.; Fahim, M.; Din, N.; Ahmad, F. Evaluation of tomato genotypes against tomato mosaic virus (ToMV) and its effect on yield contributing parameters. Pak. J. Bot. 2017, 49, 1585-1592.

3. Irfan, M.; Hayat, S.; Ahmad, A. Oxidative stress management in plants. Regulation of antioxidant system under biotic stress in plants. Chapter 14. In Antioxidants; Parvaz, A., Umar, S., Eds.; Springer: Berlin/Heidelberg, Germany, 2011; pp. 283-303.

4. Shetty, N.P.; Jorgensen, H.J.L.; Jensen, J.; Collinge, D.; Shetty, H.S. Roles of reactive oxygen species in interactions between plants and pathogens. Eur. J. Plant Pathol. 2008, 121, 267-280. [CrossRef]

5. Baxter, A.; Mittler, R.; Suzuki, N. ROS as key players in plant stress signalling. J. Exp. Bot. 2014, 65, 1229-1240. [CrossRef] [PubMed]

6. Hernández, J.A.; Gullner, G.; Clemente-Moreno, M.J.; Künstler, A.; Juhász, C.; Díaz-Vivancos, P.; Király, L. Oxidative stress and antioxidative responses in plant-virus interactions. Physiol. Mol. Plant Pathol. 2016, 94, 134-148. [CrossRef]

7. Luna, E.; Bruce, T.J.A.; Roberts, M.R.; Flors, V.; Ton, J. Next-generation systemic acquired resistance. Plant Physiol. 2012, 158, 844-853. [CrossRef] [PubMed]

8. Ryals, J.A.; Neuenschwander, U.H.; Willits, M.G.; Molina, A.; Steiner, H.-Y.; Hunt, M.D. Systemic acquired resistance. Plant Cell 1996, 8, 1809-1819. [CrossRef] [PubMed]

9. Király, L.; Barna, B.; Király, Z. Plant resistance to pathogen infection: Forms and mechanisms of innate and acquired resistance. J. Phytopathol. 2007, 155, 385-396. [CrossRef]

10. Pfitzner, A.J.P. Resistance to tobacco mosaic virus and tomatomosaic virus in tomato. Chapter B4. In Natural Resistance Mechanisms of Plants to Viruses; Loebenstein, G., Carr, J.P., Eds.; Springer: Berlin/Heidelberg, Germany, 2006; pp. 399-413.

11. Stoimenova, E.; Bogatzevska, N. Tomato mosaic virus induced systemic resistance against bacterial spot and speck diseases in tomato. Plant Prot. 2006, 17, 109-115.

12. Stoimenova, E.; Bogatzevska, N. Tomato mosaic virus induced systemic resistance against single and mix bacterial infection of Pseudomonas syringae pv. tomato and Xanthomonas vesicatoria on tomato. Plant Prot. 2008, 19, 70-73.

13. Stoimenova, E.; Bogatzevska, N. Systemic acquired resistance induced by salicylic acid and tomato mosaic virus against bacterial spot and speck diseases in tomato. Plant Prot. 2009, 20, 100-104.

14. Anfoka, G.; Buchenauer, H. Systemic acquired resistance in tomato against Phytophthora infestans by pre-inoculation with tobacco necrosis virus. Physiol. Mol. Plant. Pathol. 1997, 50, 85-101. [CrossRef]

15. Kang, B.C.; Yeam, I.; Jahn, M.M. Genetics of plant virus resistance. Ann. Rev. Phytopathol. 2005, 43, 581-621. [CrossRef] [PubMed]

16. Conrath, U. Systemic acquired resistance. Plant Signal. Behav. 2006, 1, 179-184. [CrossRef] [PubMed]

17. Chambers, S.; Merriman, P. Perennation and control of Pseudomonas tomato in Victoria. Austr. J. Agric. Res. 1975, 26, 657-663. [CrossRef]

18. Sotirova, V.; Beleva, L. Resistance of wild species, varieties and cultivars to Xanthomonas vesicatoria (Doidge) Dowson. C. R. Acad. Agric. 1975, 8, 43-47.

19. Bates, L. Rapid determination of free proline content for water stress studies. Plant Soil 1973, 39, $205-207$. [CrossRef]

20. Swain, T.; Goldstein, L. Methods in Polyphenol Chemistry; Pridham, J.B., Ed.; Pergamon Press: Oxford, UK, 1964; pp. 131-146.

21. Ellman, G.L. Tissue sulfhydryl groups. Arch. Biochem. Biophys. 1959, 82, 70-75. [CrossRef] 
22. Alexieva, V.; Sergiev, I.; Mapelli, S.; Karanov, E. The effect of drought and ultraviolet radiation on growth and stress markers in pea and wheat. Plant Cell Environ. 2001, 24, 1337-1344. [CrossRef]

23. Kramer, G.; Norman, H.; Krizek, D.; Mirecki, R. Influence of UV-B radiation on polyamines, lipid peroxidation and membrane lipids in cucumber. Phytochemistry 1991, 30, 2101-2108. [CrossRef]

24. Beauchamp, C.; Fridovich, I. Superoxide dismutase. Improved assay and an assay applicable to acrylamide gels. Anal. Biochem. 1971, 44, 276-287. [CrossRef]

25. Dias, I.; Costa, M. Effect of low salt concentration on nitrate reductase and peroxidase of sugar beet leaves. J. Exp. Bot. 1983, 34, 197-202. [CrossRef]

26. Aebi, M. Catalase in vitro. Methods Enzymol. 1984, 105, 121-126. [PubMed]

27. Meshi, T.; Motoyoshi, F.; Maeda, T.; Yoshiwoka, S.; Watanabe, H.; Okada, Y. Mutations in the tobacco mosaic virus 30-kD protein gene overcome Tm-2 resistance in tomato. Plant Cell 1989, 1, 515-522. [CrossRef] [PubMed]

28. Strasser, M.; Pfitzner, A.J. The double-resistance-breaking Tomato mosaic virus strain ToMV1-2 contains two independent single resistance-breaking domains. Arch. Virol. 2007, 152, 903-914. [CrossRef]

29. Zitter, T. Tobacco Mosaic Virus (TMV) Control; Cornell University: Ithaca, NY, USA, 2012. Available online: https://cuaes.cals.cornell.edu/sites/cuaes.cals.cornell.edu/files/shared/documents/TMV_ToMV_ CALS_TomZitter.pdf (accessed on 13 July 2020).

30. Gill, S.S.; Tuteja, N. Reactive oxygen species and antioxidant machinery in abiotic stress tolerance in crop plants. Plant Physiol. Biochem. 2010, 48, 909-930. [CrossRef]

31. Gholi-Tolouie, S.; Sokhandan-Bashir, N.; Davari, M.; Sedghi, M. The effect of salicylic and jasmonic acids on tomato physiology and tolerance to Cucumber mosaic virus (CMV). Eur. J. Plant Pathol. 2018, 151, 101-116. [CrossRef]

32. Ramos, O.F.; Smith, C.M.; Fritz, A.K.; Madl, R.L. Salicylic acid-mediated synthetic elicitors of systemic acquired resistance administered to wheat plants at jointing stage induced phenolics in mature grains. Crop Sci. 2017, 57, 3122-3128. [CrossRef]

33. Anuradha, C.; Selvarajan, R.; Vasantha, S.; Suresha, G.S. Biochemical characterization of compatible plant virus interaction: A case study with bunchy top virus-banana host-pathosystem. Plant Pathol. J. 2015, 14, 212-222. [CrossRef]

34. Balogun, O.S.; Teraoka, T. Time-course analysis of the accumulation of phenols in tomato seedlings infected with Potato Virus X and Tobacco mosaic virus. Biokemistri 2004, 16, 112-120. [CrossRef]

35. Mahjabeen; Akhtar, K.P.; Sarwar, N.; Saleem, M.Y.; Asghar, M.; Iqbal, Q.; Jamil, F.F. Effect of cucumber mosaic virus infection on morphology, yield and phenolic contents of tomato. Arch. Phytopathol. Plant Prot. 2012, 45, 766-782. [CrossRef]

36. Hassan, O.; Chang, T.; Hossain, A. Changes in the secondary compounds of persimmon leaves as a defense against circular leaf spot caused by Plurivorosphaerella nawae. PloS ONE 2020, 15, e0230286. [CrossRef] [PubMed]

37. Kuzniak, E. The ascorbate-glutathione cycle and related redox signals in plant-pathogen interactions. In Ascorbate-Glutahione Pathway and Stress Tolerance in Plants; Anjum, N.A., Umar, S., Chan, M.-T., Eds.; Springer: Dordrecht, Germany, 2010; pp. 115-136.

38. Gullner, G.; Zechmann, B.; Künstler, A.; Király, L. The signaling roles of glutathione in plant disease resistance. Chapter 15. In Glutathione in Plant Growth, Development, and Stress Tolerance; Hossain, M.A., Mostofa, M.G., Diaz-Vivancos, P., Burritt, D.J., Fujita, M., Tran, L.-S.P., Eds.; Springer: Cham, Switzerland, 2017; pp. 331-337. ISBN 978-3-319-66682-2.

39. Künstler, A.; Király, L.; Kátay, G.; Enyedi, A.J.; Gullner, G. Glutathione can compensate for salicylic acid defciency in tobacco to maintain resistance to Tobacco Mosaic Virus. Front. Plant Sci. 2019, 10, 1115. [CrossRef] [PubMed]

40. Nagai, A.; Torres, P.B.; Duarte, L.M.L.; Chaves, A.L.R.; Macedo, A.F.; Floh, E.I.S.; de Oliveira, L.F.; Zuccarelli, R.; dos Santos, D.Y.A.C. Signaling pathway played by salicylic acid, gentisic acid, nitric oxide, polyamines and non-enzymatic antioxidants in compatible and incompatible Solanum-tomato mottle mosaic virus interactions. Plant Sci. 2020, 290, 110274. [CrossRef] [PubMed]

41. Fabro, G.; Kovács, I.; Pavet, V.; Szabados, L.; Alvarez, M.E. Proline accumulation and AtP5CS2 gene activation are induced by plant-pathogen incompatible interactions in Arabidopsis. Mol. Plant Microbe Interact. 2004, 17, 343-350. [CrossRef] 
42. Gholi-Tolouie, S.; Davari, M.; Sokhandan-Bashir, N.; Sedghi, M. Influence of salicylic and jasmonic acids on the antioxidant systems of tomato (Solanum lycopersicum cv. Superchief) plants under biotic stresses'. Iran. J. Plant Physiol. 2018, 8, 2345-2351.

43. Jiang, J.-F.; Li, J.-G.; Dong, Y.-H. Effect of calcium nutrition on resistance of tomato against bacterial wilt induced by Ralstonia solanacearum. Eur. J. Plant Pathol. 2013, 136, 547-555. [CrossRef]

44. Almagro, L.; Gomez Ros, L.V.; Belchi-Navarro, S.; Bru, R.; Ros Barcelo, A.; Pedreno, M.A. Class III peroxidases in plant defence reactions. J. Exp. Bot. 2009, 60, 377-390. [CrossRef]

45. Chassot, C.; Buchala, A.; Schoonbeek, H.-J.; Metraux, J.-P.; Lamotte, O. Wounding of Arabidopsis leaves causes a powerful but transient protection against Botrytis infection. Plant J. 2008, 55, 555-567. [CrossRef]

(C) 2020 by the authors. Licensee MDPI, Basel, Switzerland. This article is an open access article distributed under the terms and conditions of the Creative Commons Attribution (CC BY) license (http://creativecommons.org/licenses/by/4.0/). 